\title{
ГРЕЧИХА - ЗОЛУШКА НА ПУТИ К ПРИНЦЕCCE
}

\section{Здоровая пища - активное долголетие}

Тренд «здоровая пища» уверенно набирает популярность. Прогресс профилактической медицины, диетологии, развитие пищевых технологий убедительно показывают зависимость качества жизни от рациона питания человека. Высокое качество жизни - это продолжительность активного долголетия.

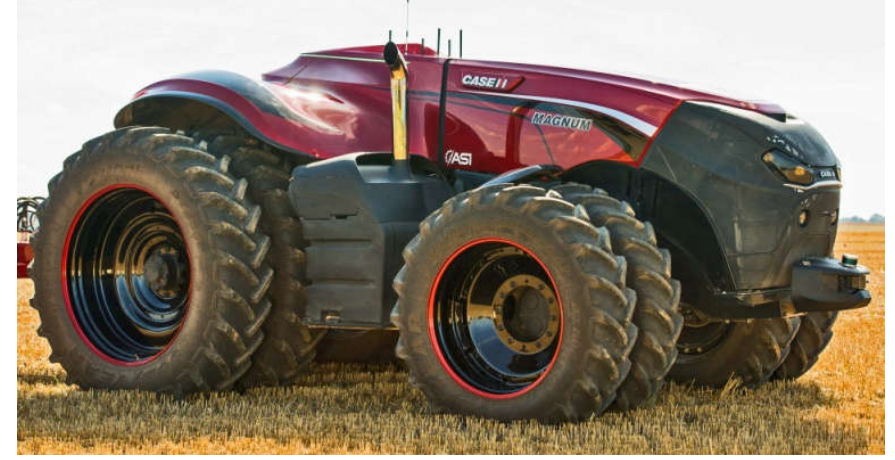

Pис. 1 - Трактор-робот Case IH

За время одного поколения, по крайней мере, того, к которому я принадлежу, произошла революция перехода от физического труда к умственному. В качестве примера на рисунке 1 показан трактор робот. Все то же, только нет кабины. Мы вступили в эпоху прорывных технологий. При чем тут здоровая пища, подумает читатель?

Очень даже при чем. Творческая работа требует исключительно высокого уровня физического состояния человека. Снижение системной физической нагрузки, обусловленной физическим трудом, привело к необходимости изменения рациона питания от абы какого к строго сбалансированному по составу. Здоровая пища отвечает этому требованию.

Мало кто из читателей обратил внимание на референдум, проведенный в Швейцарии в 2016 году. На референдум был вынесен один вопрос - согласны ли граждане Швейцарии, чтобы каждому из них из бюджета страны ежемесячно выплачивалось пособие в сумме 2000 швейцарских долларов (это чуть меньше 2000 \$ США)?

Уважаемый читатель, обратите внимание, предлагалась выплата из бюджета, который наполняется не за счет расходования природных ресурсов, как в некоторых арабских странах, а из бюджета, который пополняется за счет внедрения новых высокоприбыльных технологий. Это первая ласточка. Именно так будет в странах, совершающих сегодня технологический прорыв.

О чем это говорит? Это говорит о том, что материальное положение граждан этих стран позволяет, без чрезмерной нагрузки на семейный бюджет, отдавать предпочтение здоровым продуктам питания, цена которых на рынке выше цены обычных продуктов.

Гречка и продукты из нее легко отвечают этому тренду. Гречка - это кладезь полезных веществ. Вот только перечисление их. Из элементов: железо, кальций, калий, фосфор, йод, цинк, фтор, молибден, кобальт; из витаминов: В1, В2, В9, ниацин

(РP), витамин Е; из кислот: малеиновая, линоленовая, щавелевая, яблочная, лимонная, фолиевая. Поэтому, не удивительно, что гречиха обладает лечебными свойствами.

\section{Гречка на столе - крепче здоровье.}

Гречка используется при варикозном расширении вен, геморрое, ревматических заболеваниях, артритах и для профилактики склероза. Высокое содержание лецитина обуславливает ее применение при заболеваниях печени, сосудистой и нервной систем. Она способна повышать двигательную активность и мотивацию.

Гречка как крупа используется для приготовления каш, запеканок, пудингов, котлет, супов. Зерно гречихи мелют на муку и ее используют для блинов, оладий, лепешек, галушек. Из смесей гречневой и пшеничной муки получают лапшу, макаронные изделия, которые традиционны для японской и итальянской кухни. Во Франции традиционные бретонские блинчики делаются из гречневой крупы.

По содержанию лизина и метионина белок гречки превосходит все крупяные культуры, для него характерна высокая усвояемость - до 78\%. Доля белка в зерне гречихи показана на рисунке 2 .

Углеводов в гречке сравнительно мало, но они долго усваиваются организмом, благодаря чему после приема пищи из гречки можно чувствовать себя сытым длительное время. При длительном хранении гречневая крупа не прогоркает и не плесневеет.

Доля

белка (\%)

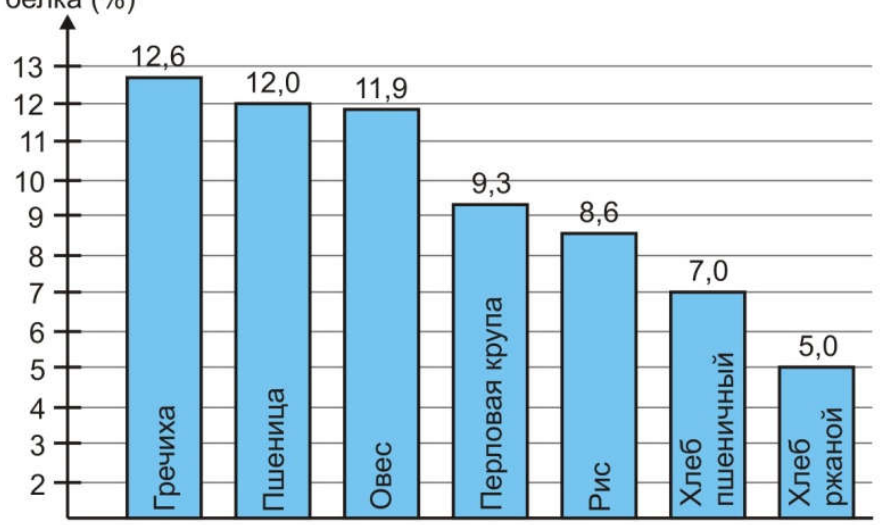

Рис. 2 - Доля белка в различных культурах и продуктах 
Гречиха - главнейшая медоносная культура. Это предопределено самой природой опыления этой культуры, как перекрестно опыляемой. Цветки гречихи дают много нектара и пыльцы. При нормальном увлажнении с одного гектара гречихи сбор меда может составлять 80-100 кг. Гречишный мед - один из высококачественных сортов меда. У этого меда очень необычный аромат и вкус, по этой причине гречишный мед не перепутаешь с другим видом меда.

В отличие от других видов меда, гречишный мед состоит из

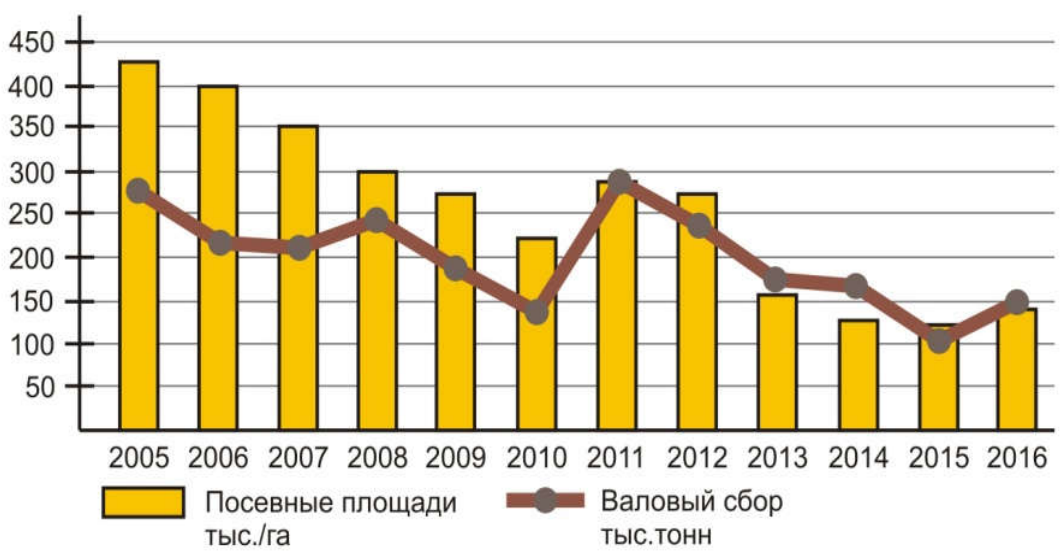

Рис. 3 - Динамика выращивания гречихи в Украине [1] большого количества белков и железа, да и минеральных веществ в нем больше по сравнению с иными видами меда. Гречишный мед помогает при многих заболеваниях, к примеру, при низком гемоглобине, малокровии и анемии. Кроме того, гречишный мед - лучшее средство при простуде, так как он природный антисептик.

Одним словом - чудо-культура, а вместе с тем, мы наблюдаем, как сложившийся мировой рынок на зерновые и технические культуры вытесняет гречиху с полей Украины. Это хорошо видно из нижеприведенного графика (рис.3).

«Невеселый» график, но статистика неоспорима. Самое простое объяснение - нерыночная культура. Нерыночная потому, что низкая урожайность и низкий спрос на мировом рынке. Кроме того, низкая культура потребления, а в отдельных странах она вообще отсутствует. Т.е. надо признать, что традиция потребления гречки не имеет широкого распространения. Хотя гречиха, как культура используемая человеком в пищу, известна давно.

\section{Гречиха вчера и сегодня.}

В литературе указываются данные, что в Северной Индии (Гималаи) гречиха была в земледелии около 2,5 тысяч лет назад. Оттуда гречиха распространилась вначале в Китай и последовательно в Среднюю Азию, Кавказ и, наконец, в Европу и Африку. В Индии гречиху называют черным рисом, в других странах Востока и Запада черной пшеницей. Название «гречиха», возможно, произошло в связи с греками, жившими на берегах Черного моря, у которых и была заимствована эта культура.

Была версия, что появление гречихи в Европе связано с татаро-монгольским нашествием, т.е. завоеватели принесли семена этого растения. Но последние археологические раскопки опровергают это утверждение. Так, при раскопках в низовьях Дона, которые относятся к I-II векам н.э., были найдены остатки гречихи. В археологических раскопках на территории Украины, относящихся к X-XII вв. н.э., также найдены следы этой культуры, т.е. задолго до вторжения монголов в Европу. Сегодня в диком виде гречиха не встречается нигде, но ученые абсолютно уверенно утверждают, что исходной дикой формой этой культуры явился широко распространенный ныне сорняк - гречиха татарская.
Сегодня гречиха производится в таких странах, как Россия, Китай, Украина, Франция, Польша, Казахстан, США, Бразилия. На долю этих стран приходится не менее 95\% мирового производства. Практически вся выращенная гречиха в странахпроизводителях идет на внутреннее потребление. Величина импорта от общего валового сбора не превышает 1,5\%. Из импортеров необходимо отметить Японию (60 тыс. тонн в год) и Францию (11 тыс. тонн в год). То, что вся производимая гречиха реализуется на внутреннем рынке, абсолютно объяснимо.

Диетологи утверждают, что необходимая доля гречневой крупы в рационе питания человека примерно 7 кг/год (системное потребление не реже одного раза в неделю). При такой норме, с учетом выхода ядрицы при обрушивании гречихи, ее необходимо производить на одного человека не менее 10 кг. Вот и получается, что в Украине только внутреннее потребление требует производства не менее 300 тыс. тонн в год. А по факту за последние четыре года (2013-2016 гг.) среднегодовой валовый сбор гречихи составлял менее половины от необходимого ( 140 тыс. тонн). Но на сегодня имеются все предпосылки к росту востребования экологически чистой гречихи в странах Европы, и только это может стать мотивацией для украинского фермера, но об этом речь пойдет далее.

Без какой-либо симпатии к бывшему колхозному строю с его трудоднями, нельзя не сказать, что в те, ныне клятые времена, гречихой украинской селекции засевались гречкосеющие регионы Ставрополья, Алтайского края, Брянской области и др. Но даже та плановая система не позволяла устранить дефицит гречки. Гречка распределялась по санаторнокурортным заведениям, армейским и другим закрытым организациям.

Ныне рынок. И, кроме толкования о пользе гречихи, нужны рыночные мотивации для роста и производства гречихи. Это, прежде всего, повышение рентабельности при товарном ее производстве и расширение производства экологически чистой греч$\boldsymbol{\kappa} \boldsymbol{u}$ для поставки ее в страны Европы. Все основания для этого есть.

\section{Агротехнология гречихи.}

В Украине сохранились научные центры по селекции гречихи и это, прежде всего, «Институт 
крупяных культур», что в Каменец-Подольском, в истоках которого стояла известный селекционер О.С. Алексеева, ННЦ «Институт земледелия НААН», селекцию гречихи в котором ведет доктор биологических наук Л.К. Тараненко, и Институт сельского хозяйства Северного Востока НААН под руководством В.М. Кабанец.

Сегодня, по утверждению Л.К. Тараненко, уровень потенциальной урожайности новых сортов составляет 3,5-4,9 т/га. Такой потенциал показывают те сорта, у которых в результате селекционных достижений интегральный показатель фотосинтеза удалось повысить с 2,9-3,1 до 4,14-4,16. К таким сортам относятся сорта, приведенные в табл. 1 [2].

Совместные сорта гречихи селекции «ННЦ Института земледелия» и НВМП «Антария» занимают около 50\% посевных площадей, отведенных под гречиху [2].

Кратко рассмотрим агротехнологию выращивания гречихи.

Одним из преимуществ гречихи является то, что она толерантна к срокам сева. А это значит, что ее можно рассматривать как страховую культуру на случай пересева озимых. Этому способствует и то, что гречиха имеет короткий вегетационный период 75-80 дней, что гарантирует ее дозревание как страховой культуры.

Уважаемый читатель, в специальной литературе без труда можно найти необходимую информацию по защите гречихи от болезней и вредителей. Поскольку мы производим оборудование для предпосевной обработки семян, то я просто перечислю те болезни гречихи и тех вредителей, которые могут передаваться семенами, а при их обработке перед севом эта угроза будет устранена. К таким болезням относятся: фитофтороз, пероноспороз, серая гниль, аскохитоз

В целом же, агрономы хорошо знают, что интегральная защита полевых культур, включая гречuxy, зависит от многих факторов, таких как выбор сорта, предшественник, подготовка семян, удобрения, обработка поля, сев и другое. Главное то, что сильное растение лучше противостоит болезням и вредителям.

Внесение основных удобрений в зависимости от естественного агрофона может варьироваться в широком диапазоне $\mathrm{N}_{30-60} \mathrm{P}_{45-60} \mathrm{~K}_{30-60}$. В целом, гречиха очень отзывчива на внесение удобрений. Так, результаты исследования ученых ННЦ «Института земледелия УААН» [3] показали, что урожайность при внесении удобрений $\mathrm{N}_{45} \mathrm{P}_{45} \mathrm{R}_{45}$ составила 25 ц/га по сравнению с контролем (без удобрений) 14,3 ц/га.

Сегодня агрономическая наука убедительно

Таблица 1 - Урожайность гречихи

\begin{tabular}{||c||c||c||}
\hline \hline Сорт & $\begin{array}{c}\text { Средняя уро- } \\
\text { жайность } 3 \boldsymbol{a} \\
\text { годы испьтаний } \\
(\mathbf{u} / 2 \boldsymbol{a})\end{array}$ & $\begin{array}{c}\text { Максимальная } \\
\text { урожайность } \\
\text { (и/га) }\end{array}$ \\
\hline \hline СИН-3/02 & $20,9-38,8$ & 41,3 \\
\hline \hline Антария & $21,6-36,8$ & \\
\hline \hline София & & 42,6 \\
\hline \hline Воля & 32 & 49 \\
\hline
\end{tabular}

доказала верность закона-минимума, сформулированного Либихом более 150 лет тому назад. Дефицит каких-либо отдельных элементов может существенно повлиять на урожайность. Экспериментально доказано важное значение для крупяных культур таких микроэлементов, как бор, медь, молибден, цинк и марганец. Наиболее эффективный способ их применения - предпосевная обработка семян. На 1 тонну семян используют 50-100 г. сернокислого марганца, 50 г. сернокислого цинка и молибдена и 150 г. борной кислоты.

Что касается гречихи, то на нее сильно влияет дефицит бора - отмирают цветочные почки, цветы и даже плоды в начале их завязи. Для предупреждения этого семена гречихи обрабатывают перед севом раствором борной кислоты (200-300 г/т).

Кроме того, современная наука убедительно показала необходимость обработки любых семян микробными инокулянтами. Понятно, что азотфиксирующие микроорганизмы, внесенные в объем корневой системы, вместе с семенами гречихи работают не так эффективно, как в симбиозе с корнями бобовых культур, но, тем не менее, работают и обеспечивают защиту корней от патогенной грунтовой микрофлоры.

Органические удобрения, внесенные под гречиху, вызывают чрезмерное развитие самого растения, задерживают начало репродуктивной фазы и, тем самым, снижают урожайность. В то же время гречиха хорошо реагирует на органические удобрения, внесенные под предшественник.

Несмотря на то, что гречиха выносит с урожаем большое количество питательных веществ (1 тонна продукции - 35-45 кг N, 12-17 кг $\mathrm{P}_{2} \mathrm{O}_{5}, 35-50$ кг $\mathrm{K}_{2} \mathrm{O}$ ), оставленные в поле пожнивные остатки возвращают в поле фосфор, калий и кальций в количестве в 2,5-3 раза больше, чем пожнивные остатки других зерновых культур. Все это с учетом состояния верхнего слоя почвы, оставшихся в поле корней гречихи и пожнивных остатков, снижает долю внесения удобрений для последующей культуры.

Несмотря на то, что у гречихи глубина отдельных корней может достигать два метра, основная их масса чрезвычайно развита в верхней части поля. Огромное количество тонких корешков и волосков позволяет усваивать запасы почвенных удобрений намного эффективнее, чем у зерновых культур. Кроме этого, такая корневая система так разрыхляет верхний слой почвы и обеспечивает аэрацию ему, что исключает необходимость пахоты перед севом следующей культуры.

Еще одна особенность гречки в том, что у нее нет четкой грани между окончанием роста и началом генеративного развития. Ростовые процессы корневой системы не прекращаются на продолжении всей жизни растения.

Гречиха хорошо развивается в грунтах, кислотность которых $\mathrm{pH}=5-7$. На производство единицы сухой продукции гречиха поглощает воды в два раза больше, чем пшеница, и в три раза больше, чем просо. Особенно высокая потребность в воде приходится на начало роста и на фазу цветения и начало завязи. 


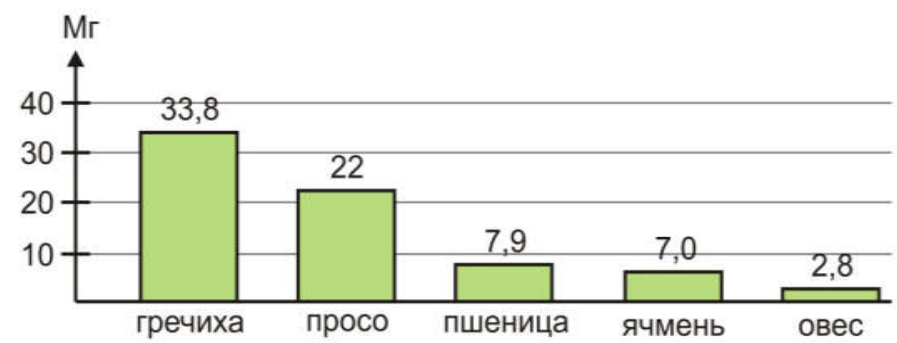

Рис. 4 - Количество усвояемых питательных элементов (мг) в расчете на 12 корней различными зерновыми культурами

От наличия дождей в этой фазе сильно зависит урожайность гречихи.

У гречихи есть явные преимущества в поддержании как развитого, так и короткого севооборота. Кроме того, она не снижает урожайности на второй год на том же поле. В силу короткой вегетации гречиха убирается рано, что позволяет в полной мере подготовить поле к севу озимых, тем более что достаточно будет неглубокого дискования в предпосевной подготовке.

И.М. Марусяк [4], руководитель сельхозкооператива «Ратай», как он сам себя называет «гречкосій із діда-прадіда», утверждает, что озимая пшеница, посеянная по гречихе, дает такой же самый урожай, что и озимая пшеница по гороху.

Гречиху высевают с различной величиной междурядья. Такой сев позволяет выполнять междурядную обработку, которая, кроме удаления сорняков, позволяет подгортать землей стебель на 7-8 см. Это приводит к тому, что в подсыпаемом слое почвы от стебля прорастают новые корни, что обеспечивает усиление корневой системы и растения в целом.

Обработка гречихи гербицидами весьма ограничена. Дело в том, что не будет опыления пчелами, не будет и урожая. На каждый гектар требуется 2,-2,5 пчелиной семьи. Цветок гречихи живет один день. Утром произошло опыление - будет завязь, не случилось этого - во второй половине дня цветок отмирает. И при этом процесс увядания имеет длительный период, нижние завязи формируются в семена, а цветение растения продолжается. Агроном должен создать все условия для благоприятных условий работы пчел. Именно этим объясняется ограничение использования гербицидов при борьбе с сорняками на полях гречихи.

Длительность периода цветения предопределяет то, что на полях гречихи не допускается десикация. А это, в свою очередь, делает целесообразным раздельный способ уборки. В скошенных валках зерно частично дозревает, подсыхает и обмолачивается с минимальными потерями.

Корневая система гречихи характеризуется очень высокой физиологической активностью. Так гречиха, уступая пшенице по массе корней в 2,4 раза, превосходит ее по поглотительной способности в 2,7 раза.

Из всех полевых культур гречиха обладает наибольшей способностью синтезировать органические кислоты (7 мг кислот на 1 г сухого вещества, а кукуруза - 1 мг). Гречиха лучше других зерновых культур усваивает элементы питания из почвы и поэтому требовательна к наличию в ней легкорастворимых соединений. Рисунок 4 наглядно это показывает.

Норма высева гречихи 4-5 млн. всхожих семян на 1 га. При широкорядном посеве (45 см) норма высева снижается до 3 млн. Масса 1000 шт. семян 25-30 г. Содержание белка 15-16\%, крахмала 71-72\%, жира 3\%. Размеры семян гречихи: длина 4,2-8; ширина 2,8-5,2; толщина 2-4,2. Созревает неравномерно: нижние созревшие семена легко обмолачиваются и осыпаются, тогда как верхушка бывает еще покрыта цветами.

Остановить умерщвление почвы - задача нашего поколения.

Уважаемый читатель, мировой агробизнес, в основе которого лежит интенсивная технология производства с/х культур, медленно, но неуклонно движется к тупику, который на сегодняшний день стал уже реально осязаем. За последние пятьдесят лет урожайность основных культур удвоилась за счет, в основном, внесения химических удобрений, а количество вносимых удобрений за это же время увеличилось в десять раз.

Все бы ничего, но такая технология, а именно пахота и химудобрения, уничтожают почвенную биоту, которая формировалась миллионы лет и благодаря которой появилась на Земле растительность и животный мир, включая человека. Вот он и тупик. Вроде и без химии нельзя, а если на этом пути не остановиться, то планета нас сбросит.

Понятно, что этого не произойдет. Более того, аналитики утверждают, что население нашей планеты вырастет до 9,5 млрд. человек. Расчеты показывают, что именно столько людей смогут прокормиться, используя имеющийся ресурс производства продуктов питания. Это возможно только за счет медленного, но неизбежного перехода от химудобрений и средств защиты на биопрепараты и перехода от пахотного к щадящему принципу землеобработки.

Ведущие агрогиганты, такие как Bayer, Monsanto, DuPont, Syngenta, BasF, Arysta уже сегодня вкладывают огромные деньги как на исследования эффективности биопрепаратов, так и в их производство и вывод на рынок. Указанные наднациональные агрогиганты либо создают свои научные центры, либо приобретают акции научных организаций, добившихся прорывов микробиологических исследований. Так, Bayer заплатил 425 млн. \$ за исследования в этом направлении фирме ArgoQuest, a DuPont приобрела фирму Taxon Biosciences, Monsanto выкупила акции компании Agradis Synthetic Genomics, специализирующейся на микробиологических исследованиях.

Объем рынка микробных препаратов уже сегодня около 5 млрд. \$, а к 2020 году прогнозируют рост объема продаж до уровня 8 млрд. \$.

Как правило, мы мыслим категориями, отвечающие требованиям среды, в которой мы живем. Макромир (Вселенная бесконечна) и микромир (нано $\left.-1 \mathrm{M}^{-9}\right)$ нами воспринимается с трудом. 
Мы с трудом можем представить, что в 1 г плодородной почвы 1 млрд. бактерий, а в одном грамме почвы, где активно применяются химические удобрения и средства защиты, микроорганизмов всего 10 тысяч, то есть в сто тысяч раз меньше, чем в живой почве.

По мнению ведущих специалистов, если стоит вопрос о высоких урожаях, полный отказ от химии невозможен. Отдельная речь об органическом земледелии, где химия в принципе не применима. Об этом чуть позже.

Дело в том, что с помощью биопрепаратов можно существенно снизить долю вносимых химических препаратов. Биопрепараты в объеме корневой системы существенно повышают усвояемость питательных веществ, привнесенных в почву. Как известно, доля усвоения химудобрений, в среднем, не превышает $30 \%$ от внесенной дозы в почву. Биологические препараты в состоянии повысить усвояемость в два раза, что позволит снизить химическую нагрузку на почву. Сильная корневая система, сильное растение, высокий иммунитет обеспечит устойчивость растения к стрессу, а значит, позволит снизить и дозу химпрепаратов защитного действия.

Однако вернемся к основной теме материала - гречихе. Необходимо отметить, что в Украине производятся биологические препараты, отвечающие требованиям Европейского Союза как пригодные для органического земледелия. Производителями таких препаратов являются TD «Энзим-Агро» и Институт сельскохозяйственной микробиологии и агропромышленного производства НААН. Учеными этого института разработан и выпускается препарат «Диазобактерин» для предпосевной обработки семян различных с/х культур, в том числе и семян гречихи.

Препарат безвреден для людей и животных, не загрязняет среду. Препарат повышает активность процесса фиксации атмосферного азота, что позволяет снизить дозу вносимого азота на 30-60 кг/га [5]. Препарат повышает качество и количество белка в зерне, количество заменимых аминокислот. Так, соотношение незаменимых/заменимых аминокислот в зерне при обработке семян препаратом составило 0,71 , а без обработки 0,68 . Это соотношение очень важно для гречки, поскольку она используется в диетических продуктах и детском питании.

Бактеризованные растения гречки на 3-5 дней раньше зацветают, за счет чего увеличивается период формирования зерна, что сказывается на выполненности зерен и на общей продуктивности. Многолетние полевые испытания в разных областях Украины показали высокую эффективность «Диазобактерина». Так урожайность возросла на 15-50\%, а количество незаменимых аминокислот на 20-30\%.

Для защиты посевов гречихи от вредителей также имеются эффективные биопрепараты. Ученые Института защиты растений НААН предлагают для этого использовать препараты «Битоксибацилин» и «Актофит» [6].

На рисунке 5 приведена эффективность обработки полей гречихи против тли. Хорошо видно, что количество вредителей уменьшается в 3-4 раза и даже через 14 дней популяция вредителей практически не возросла.

Биопрепараты для обработки полей против вредителей гречихи исключительно значимы по той причине, что цветение гречихи занимает длительный период, и необходимо создать условия для её опыления насекомыми. Отпугнем пчелу - не получим урожай.

Чем больше узнаешь о гречихе, тем большей симпатией к ней проникаешься. И прежде всего от того, что эта культура для думающего фермера. Не будут холдинги нею заниматься - не идет эта культура морскими баржами на мировой рынок. Пока не идет.

А для фермера, ведущего севооборот, это культура чрезвычайно подходящая. Ее выращивают в послеукосных посевах, в бинарных посевах (например, с другой крупяной культурой - просом), ее высевают в технологии No-Till после уборки озимой пшеницы и успевают убрать поздней осенью, ее выращивают по экотехнологии. Но все по порядку. Bax [7].

Выращивание гречихи в послеукосных посе-

В послеукосных посевах гречихи вегетативный период ее уменьшается на 10-15 дней, особенно это проявляется при севе среднеспелых сортов. Послеукосный сев гречихи выполняют после уборки озимых колосовых на зеленый корм, а также после смеси яровых колосовых и бобовых культур на зеленый корм или сено [7].

Перед севом семена для защиты от болезней и вредителей обрабатывают биологическими препаратами и инокулянтами, включающими в себя азотфиксирующие и фосфоромобилизирующие бактерии. Заделку семян заглубляют на 1-2 см, но, тем не менее, семена прорастают через 6-8 дней против весенних 10-12 дней.

Рядный посев позволяет выполнять борьбу с сорняками без гербицидов исключительно за счет междурядной обработки и подгортания почвы под 
стебель растения. Целесообразно обрабатывать растения биорегуляторами роста.

Наличие 2-3 семей пчел на гектар обязательно. Уборка раздельная, при влажности зерна 15$16 \%$ валки в поле сохнут 5-7 дней. Срез при уборке на уровне $30 \mathrm{~cm}$, направление укоса либо поперек рядка, либо под углом. Это позволяет уложить рядок так, чтобы он не касался земли.

Выращивание гречихи в послеукосной технологии позволяет упростить борьбу с сорняками, обеспечить хорошую аэрацию верхнего слоя почвы и тем самым подготовить поле для сева последующих яровых культур.

\section{Бинарные посевы - двойной выцгрыш.}

Ученые Подольского государственного аграрно-технического университета в течение нескольких лет (2013-2016 гг.) выполняли уникальные полевые исследования по эффективности бинарных посевов крупяных культур (гречиха+просо) [8]. Результаты поразительные (рис.6) и хотя в агротехнологии бинарных посевов много еще и труднообъяснимого, но уже есть много исключительно интересного материала, полученного не только на полигонах, но и на товарных посевах больших площадей.

При бинарном посеве гречихи и проса основные условия в подборе сортов гречихи и проса были: совместимость по высоте растений и совпадение основных фаз развития - вегетативной и генеративной. Сев проводился с междурядьем для гречихи 45 см, а проса двумя рядами в междурядье гречихи на расстоянии между рядами 15 см.

Уборка проводилась прямым способом при $75 \%$ побурения семян гречихи.

Разделение зерна гречихи и проса после уборки, равно как и последующая одновидовая очистка их, не составила каких-либо трудностей, поскольку разница в размерах и форме семян гречихи и проса позволила сделать это с высоким качеством.

\section{Гречиха и No-Till.}

O No-Till и других щадящих технологиях обработки почвы я пишу в каждой книжке. Поскольку добавить ничего не могу, то повторю небольшой фрагмент из книжки «Соя - культура XXI века» в той eе части, где по технологии No-Till приведены peзультаты высева гречихи после уборки озимой пшеницы фермером Войтовиком Михаилом Викторовичем, который на 300 га умудряется держать севооборот, включая гречиху.

Уже идет восьмой десяток лет после выхода книги Эдварда Фолкнера «Безумие пахаря». Но в те давние годы, да и во многие последующие, человечество (при росте населения) без пахоты было бы обречено на голодание. Плуг обеспечил рост численности людей на Земле, да и беда, которую привнес плуг, не была так очевидна - естественное плодородие снижалось медленно. Но сегодня - это сегодня. Когда стало очевидно, что мы сделали с почвой, когда мы понимаем, как надо начинать восстановление ее былого плодородия, когда создан прекрасный инструментарий для этого, когда в агротехнологии идет глобальный отказ от плуга в пользу щадящей техно

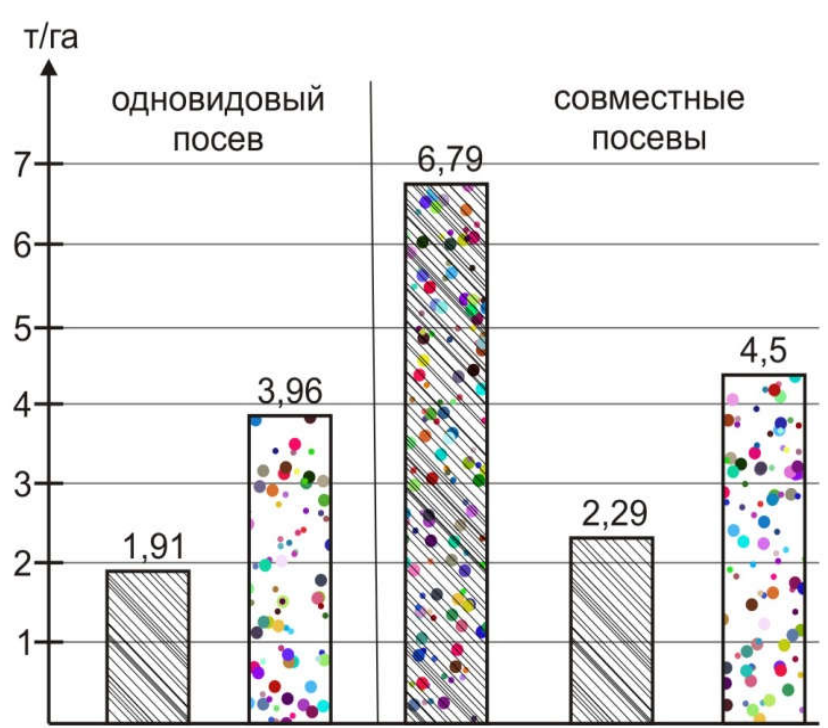

Рис. 6 - Урожайность крупяных культур в одновидовых и совместных посевах (средние значения за 2013-2016 г2.) [8]

логии обработки земли, нет-нет, да и выйдет на трибуну оратор и исполнит «гимн плугу».

В частности, так произошло на конференции «День агронома 2016». Докладчик с претензией на якобы научное обоснование воспевал преимущество глубокой отвальной пахоты. Не покидало ощущение, что сам оратор мучается от того, что надо реанимировать то, что уже опровергнуто не отдельными фермерами-новаторами, а целыми странами. После уточнения цели этой демагогии стало ясно - докладчик мотивирован зарубежной фирмой по продаже плугов в Украине, так как в стране производителей этих плугов продажи остановились.

Есть классическое толкование слова «демагог» - человек, знающий истину, но заведомо уводящий слушателей на ложный след. В нашем случае хочется перефразировать крылатую фразу Анатолия Папанова: «Кто опаснее демагога - демагог ученый», ибо у нас еще живо доверие к науке, хотя именно в землеобработке практика на многие годы обогнала науку. Прошу прощения у читателя за очередной выпад.

В таблице 2 приведена информация о севообороте при технологии No-Till, в который включена гречиха, как пожнивная культура.

\section{Гречиха - здоровый продукт.}

А теперь о главном. Когда я взялся за это повествование о гречихе, то основная цель была дать вариант фермеру для выживания, поскольку прессинг со стороны агрохолдингов можно сдержать только за счет прибыльности, обрабатывая сравнительно небольшие наделы площадей. Мне представляется, что этого можно достичь за счет выращивания экологически чистой продукции и прямой поставки ее в страны Западной Европы за заранее оговоренную цену. Путь не простой, но верный. По нему пошли уже многие фермерские хозяйства. Корень вопроса в том, что покупатель экопродукции не заключает соглашение с холдингом, поскольку там не понятно, кто персонально отвечает за контроль экотехнологии, 
Таблица 2-Cевооборот при технологии No-Till

\begin{tabular}{|c|c|}
\hline Руководитель, место нахождения & $\begin{array}{l}\text { Войтовик Михаил Викторович } \\
\text { ТОВ «Мрія», Киевская обл. } \\
\text { Белоцерковский р-н, с.Блощинцы }\end{array}$ \\
\hline $\begin{array}{l}\text { Обрабатываемая площадь, количество работ- } \\
\text { ников }\end{array}$ & 300 га; 10 человек \\
\hline Обязательства перед полем & $\begin{array}{l}15 \text { лет без пахоты. Измельченная солома остается в } \\
\text { поле }\end{array}$ \\
\hline $\begin{array}{l}\text { Благодарный ответ поля. Урожайность в } 2014 \text { г. } \\
\text { (гречиха как покрывная культура сеется вслед } \\
\text { за комбайном, убирающим пшеницу) }\end{array}$ & $\begin{array}{l}2014 \text { г. } \\
\text { Соя - 25-35 ц/га } \\
\text { Пшеница }-58-65 \text { ц/га } \\
(137 \text { га) }(2 \text { кл) } \\
\text { Гречиха }-10-11 \text { ц/га } \\
\text { (второй урожай) }\end{array}$ \\
\hline Корм для обеспечения жизни почвенной биоты & $\begin{array}{l}\text { Солома } \\
6 \text { т/га - пшеница } \\
3 \text { т/га - гречиха } \\
1 \text { тонна соломы - 3-4 т органики } \\
9 \text { т/га } \rightarrow 27-36 \text { т/га (органики) } \\
\end{array}$ \\
\hline $\begin{array}{l}\text { Земля, взрыхленная подземными пахарями - } \\
\text { червями, не уплотняется. Расход солярки на га } \\
\text { за сезон минимален }\end{array}$ & $\begin{array}{l}\text { Максимум } 6 \text { проходов по полю за сезон } \\
\text { Посев пшеницы } \rightarrow \text { два опрыскивания } \rightarrow \text { комбайн } \rightarrow \\
\text { сев гречихи } \rightarrow \text { комбайн } \\
(20 \text { л/га за сезон })\end{array}$ \\
\hline $\begin{array}{l}\text { Поле - завод по производству гумуса. Количест- } \\
\text { во работников на одном гектаре - } 1 \text { млн. } 670 \text { ты- } \\
\text { сяч штук }\end{array}$ & $\begin{array}{l}\text { Количество червей на } 1 \text { кв.метр (Киевская обл.) } \\
\text { Карапыши }-4 \text { шт./кв.м } \\
\text { Матюши }-8 \text { шт./кв.м } \\
\text { Яблоновка }-12 \text { шт./кв.м } \\
\text { Блощинцы }-167 \text { шт./кв.м }\end{array}$ \\
\hline
\end{tabular}

другое дело фермер - он в одном лице и «командир» и «начальник штаба». Есть хороший афоризм - «Мы» не краснеют, краснеет «Я».

Так вот, гречиха исключительно подходит под экотехнологию, прежде всего, как в нижеприведенном примере, из-за короткого вегетативного периода, а также как сырье для диетических продуктов и детского питания.

Так, в агрофирме «Живая земля Потуторы», что на Тернопольщине (директор И. Бойко) экогречка выращивается по следующей технологии [9].

После уборки озимых культур в сентябре высеваются смеси озимых культур - вики озимой с озимой рожью и озимым тритикале. Во второй половине мая выросшую массу вики и злаковых культур скашивают. К этому моменту вика начинает цвести, а злаковые колосятся. Зеленная масса этой смеси дает урожай 300-400 ц/га.

Вика, как бобовая культура, оставляет в поле аммонийного азота на уровне 50-80 кг/га - для гречи-

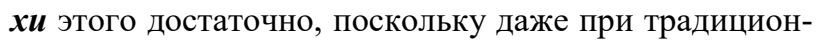
ном севе рекомендуемая норма по внесению азота для этой культуры 30-60 кг действующего вещества.

Высевается гречиха раннеспелых сортов (например, «Елена»), вегетация которых составляет 85-86 дней. Семена можно обработать нехимически- ми препаратами и инокулянтами (об этом уже было сказано).

Междурядная механическая обработка обеспечивает борьбу с сорняками, а также традиционные для гречихи 2-3 улья на гектар, раздельная уборка и очистка от растительного и минерального сора в темпе уборки позволяют получить неплохой урожай экологически чистой гречихи.

Аналогичный севооборот ведет фермер Дон А.Ф на Винничине. Гречиху сеет пожнивно после пшеницы, и если не успевает ее убрать по осени, то она остается как весенний сидерат. Это позволяет оздоровить почву и оставить в ней фосфор и калий в доступной форме для следующей культуры. Таким образом, его севооборот - пшеница, пожнивная гречuxa, соя. И все это по органической технологии.

Еще более развернутый севооборот ведет по органическому земледелию фермер Лобан В.М. на Полтавщине. Он выращивает зеленую гречиху в севообороте с такими культурами, как кукуруза, соя, овес, белая горчица, бобовые культуры, кондитерский подсолнечник.

Предпочтение зеленой гречихе отдано по той причине, что она не содержит глютена и имеет спрос на рынке Европейских стран. Лобан В.М. напрямую работает с покупателями Германии, Швейцарии, Чехии, Голландии. 
Сильные семена гречихи - высокий урожай.

Поскольку мы делаем оборудование по очистке зерна любых сельскохозяйственных культур и производству сильных семян, то преимущество предлагаемых нами решет для очистки зерна заключается в том, что, какую бы сложную форму не представляла собой зерновка, она на решете новой геометрии повернется и примерится самым малым размером. Именно так происходит взаимодействие решета и семян гречихи (рис.7). Это важно, ибо на таких решетах калибровка семян разделяет семена по выполненности, что для таких семян, как гречиха, на традиционных ситах сделать невозможно. Именно такую сепарацию по геометрии мы выполняем на наших машинах, а последующая сепарация по плотности на пневмовибростоле выделяет из посевного материала гречихи самые сильные и выровненные по семенному и урожайному потенциалу семена. Наше оборудование поставлено на фирму ТОВ НВМП «Антарія», которая готовит семена гречихи ведущих селекционеров Института земледелия НААН под руководством доктора с/х наук Тараненко Л.К.

Завод по подготовке сильных семян (рис.8) универсален для любых культур. Основное отличие его от имеющихся на рынке в том, что на нем реализуется щадящая пофракционная технология производства сильных семян.

Травмирование семян полностью исключено. Пофракционная технология позволяет строго откалибровать семена как по размеру, так и по форме. Такая подготовка семян перед сепарацией семян по плотности на пневмовибростоле позволяет, при всей внешней схожести семян, строго разделить их по семенным и урожайным качествам. В качестве при-

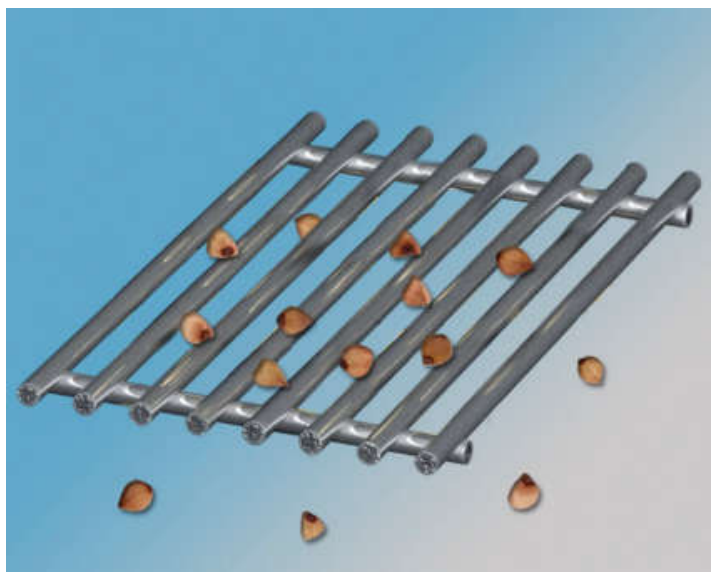

Рис. 7 - Взаимодействие решета и семян гречихи

мера на рисунке 9 приведен внешний вид семян гречихи, строго откалиброванных по размеру (сход с решета Фадеева 3,6 и проход через решето Фадеева $3,8)$ и разделенных по плотности на пневмовибростоле.

Какое-либо отличие визуально не определяется. В то же время, это две разные по плотности фракции семян, сошедшие с деки пневмовибростола. Одна партия «тяжелая» (a), другая средняя по плотности (б). На рисунке 10 приведены характеристики обеих партий.

Хорошо видно отличие массы 1000 шт. семян и натуры, но главное не это. Главное то, что при практическом совпадении процента всхожести (97\% и 96\%) существенно отличаются показатели энергии прорастания (91\% и 84\%) (рис.11). В полевой всхожести разница будет еще значительнее.

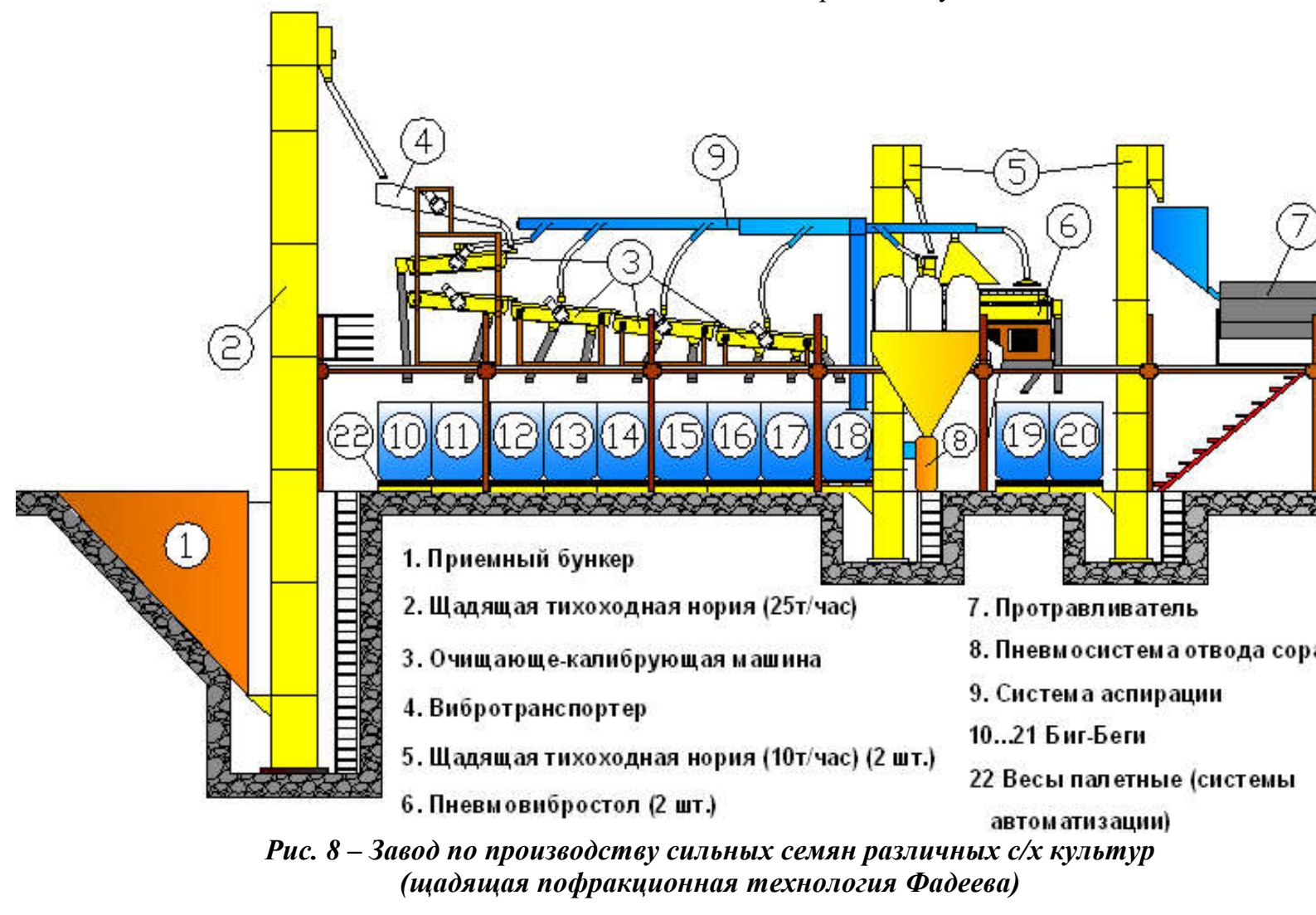




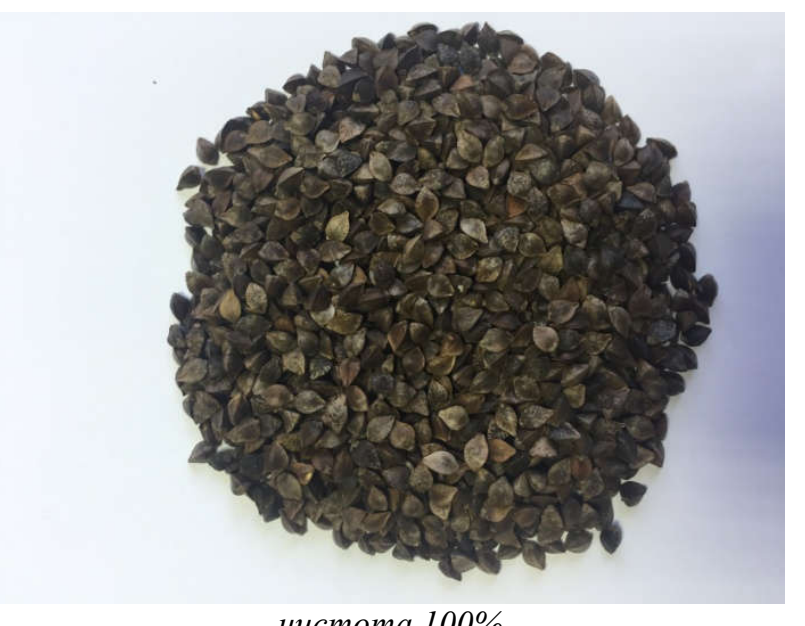

чистота $100 \%$

а) тяжелая фракциия

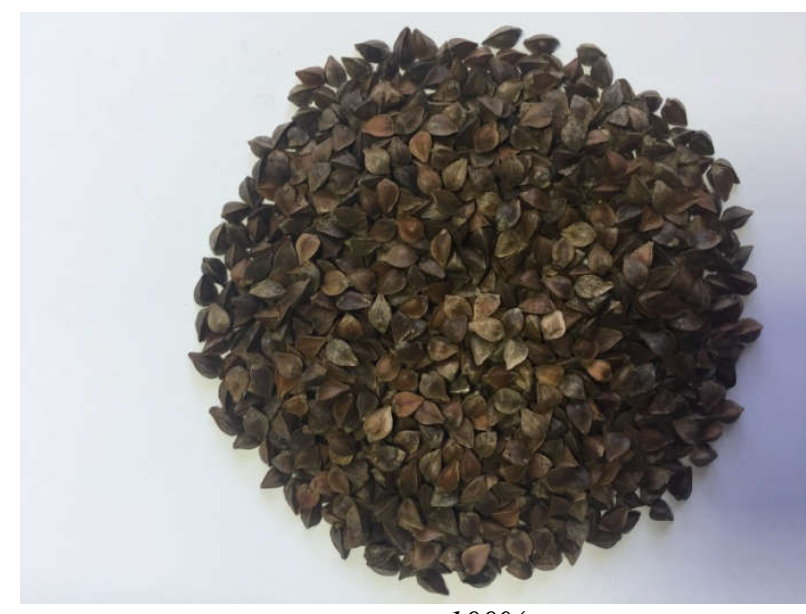

чистота $100 \%$

б) фракиия средняя по плотности

Рис. 9 - Семена гречихи после сепарации по плотности на пневмовибростоле

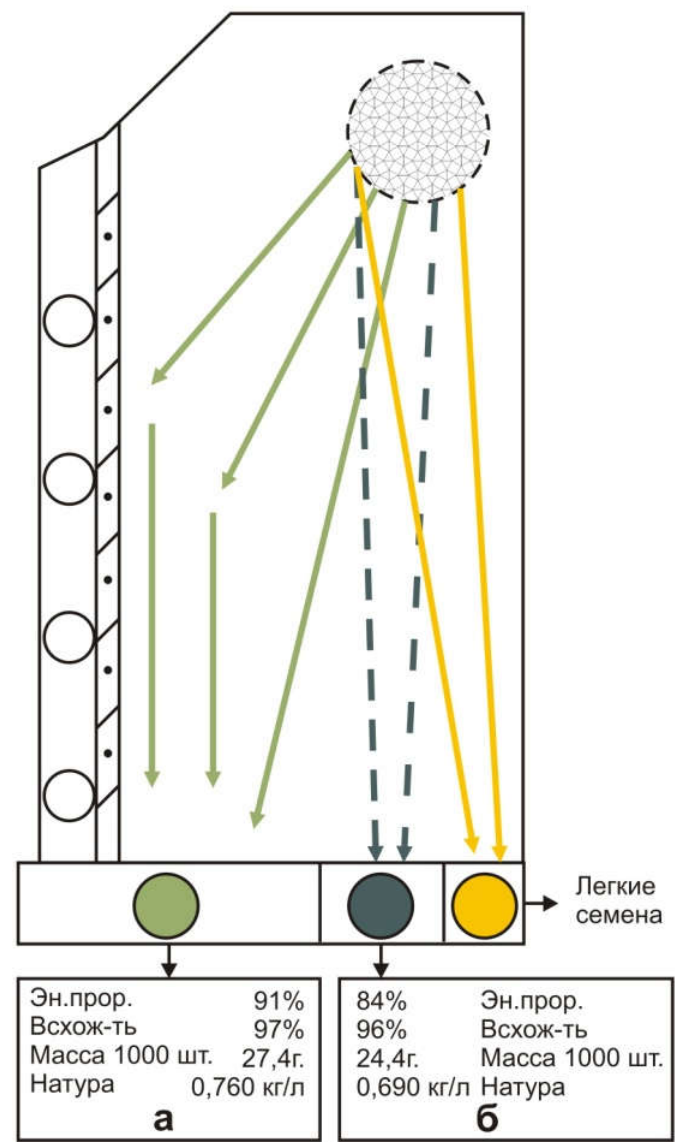

Рис. 10 - Результаты сепарации семян гречихи по плотности на пневмовибростоле (а-тяжелые семена;

б-средние семена по плотности)

В этом и заключается функция пневмовибростола, как машины способной разделить внешне абсолютно одинаковые семена на фракции по плотности, т.е. по посевным и урожайным качествам.

Поскольку современные агротехнологии настоятельно требуют обработку семян микробными препаратами, то машина для предпосевной обработки семян должна позволять нанесение инокулянта, несовмещенного в одной емкости с химпрепаратом. Именно такие машины мы устанавливаем на последнем этапе технологии подготовки семян (рис.12, 13).

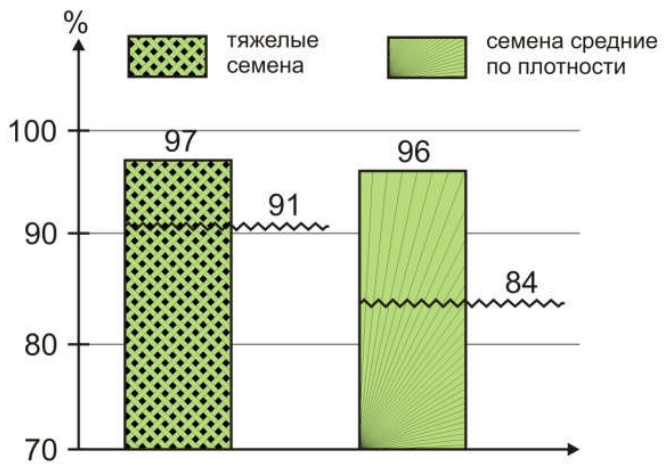

Рис. 11 - Всхожесть и энергия прорастания семян гречихи после сепарации семян на пневмовибростоле

\section{ботке семян.}

Работа комплекса по предпосевной обра-

Зерно из бункера исходного продукта (1) поступает на ленточный конвейер-дозатор (2). Привод конвейера через частотный преобразователь включен в систему автоматического поддержания заданного расхода семян. Из ленточного конвейера-дозатора зерно ссыпается в обеспыливающий аспиратор АФ-5 (3) (два аспиратора). Из аспираторов зерно ссыпается в бункер подготовительный (4), устанавливаемый на тензодатчики с целью строгого поддержания заданного расхода зерна. Уровень зерна в бункере автоматически отслеживается системой автоматического регулирования. Из подготовительного бункера зерно ссыпается по каналу в вымешиватель зерна (5).

Система подачи протравителя состоит из двух баков с вымешивателями препаратов (6) и (7), двух насосов-регуляторов (8) и (9) и двух центробежных форсунок, установленных в вымешивателе семян.

Жидкий npenapam соответствующего состава заливается в баки (емкостью по 300 л каждый), установленные на тензодатчики для непрерывного контроля расхода преnapama. Вымешиватель преnаpama поддерживает равномерную концентрацию разнокомпонентного состава (протравитель + прилипатель + краситель и т.п.). Насосы-дозаторы обеспечивают заданный расход преnapama за счет регули- 


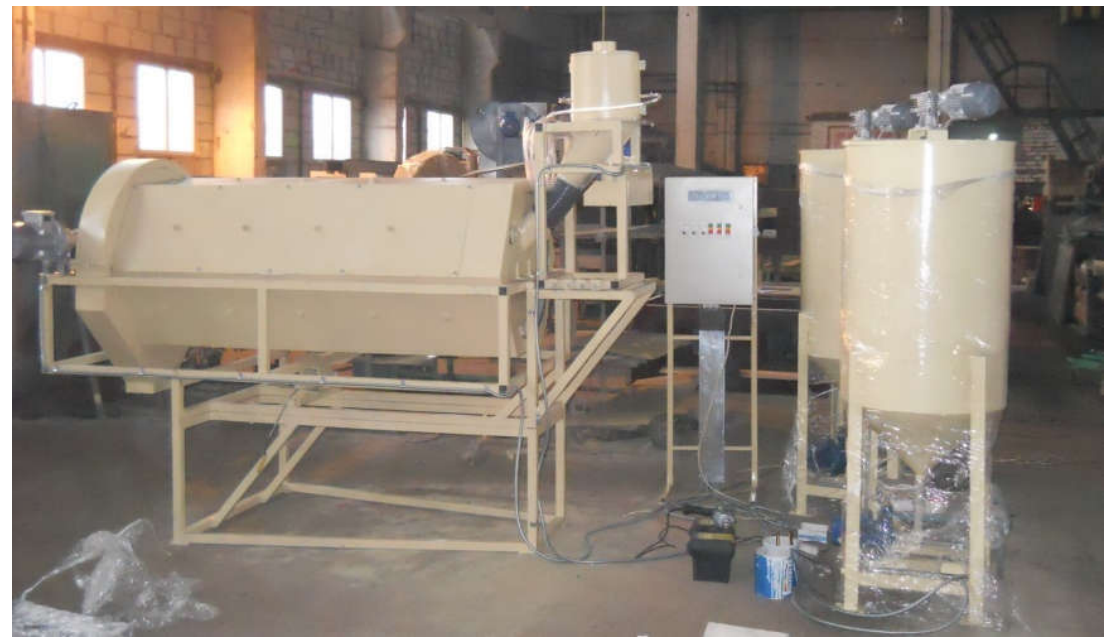

Рис. 12 - Маиина для предпосевной обработки семян (ПСФ) Протравливатель семян Фадеева (ПСФ)

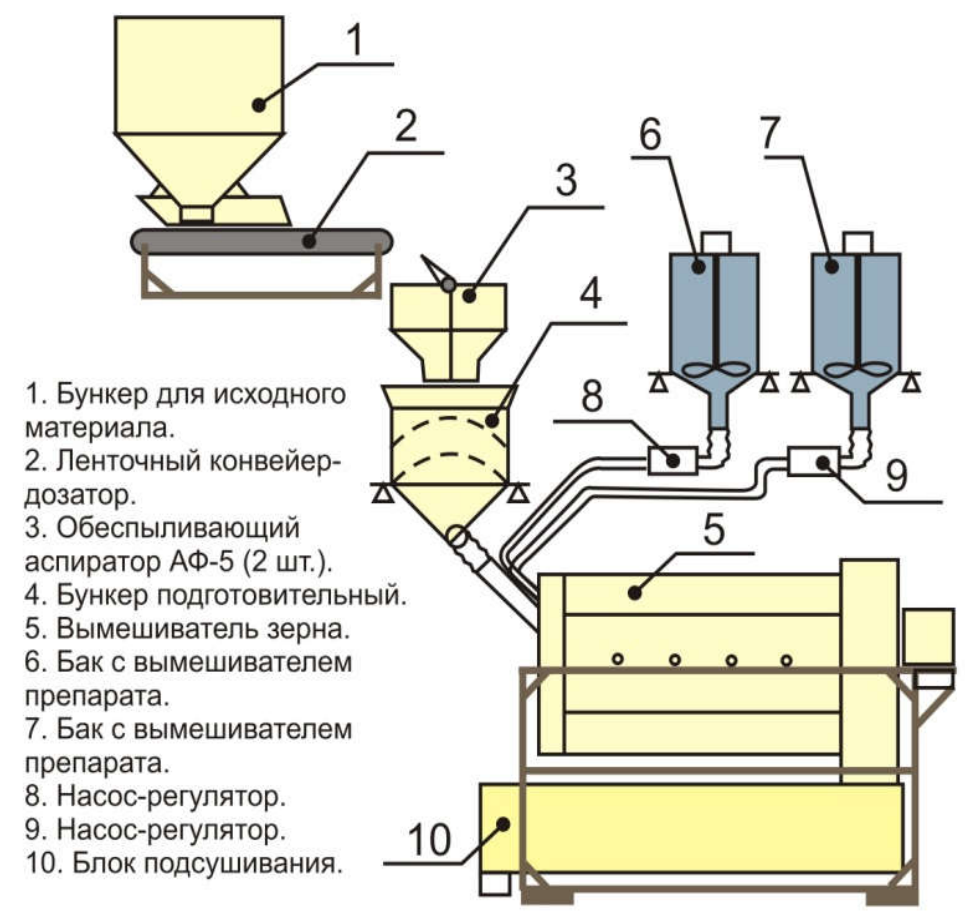

\section{Рис. 13 - Технологическая схема комплекса по предпосевной обработке семян}

рования частоты вращения приводов насосов, подключенных через частотные преобразователи к системе автоматического регулирования. Центробежные форсунки (2 шт.) распыляют препарат на непрерывно пересыпающиеся семена в вымешивателе семян.

Вымешиватель семян обеспечивает равномерное распределение преnарата по поверхности семян за счет взаимоконтактов между семянками и контакта их с развитой внутренней поверхностью камеры вымешивания в процессе непрерывного вращения камеры вымешивания семян.

Сегодня технический прогресс вторгся в самую, на мой взгляд, архаичную область - растениеводство. Основная цель повысить эффективность использования земли, не снижая ее плодородия, а еще лучше, восстанавливая плодородие.

Гречиха, как исключительно важная культура для здоровья человека, хорошо сочетающаяся в севообороте с другими культурами, подходящая под щадящую обработку земли, удачно вписывающаяся в тренд XXI века «Здоровые продукты», достойна внимания нашего фермера.

\section{ЛИТЕРАТУРА:}

1. Тараненко Л.К., д.б.н., директор ТОВ НВМП «Антарія». Виробництво гречки в Україні в сезоні 2015 року становить антирекорд./ Тараненко Л.К.// Хранение и переработка зерна. - 2015. - №8-9- августсентябрь. - С. 26.

2. Зинченко С. Селекиї присвячується./ Зинченко С.// Агро Перспектива. - 2016. - №7 - июль. - С. 76-80.

3. М.И. Драган, Р.Е. Грищенко, О.Г. Любчич ННЦ «Институт земледелия УААН». Диета для проса и гречки./ М.И. Драган, Р.Е. Грищенко, О.Г. Любчич//Зерно. - 2009. - №6- июль. - С. 81-87.

4. Людмила Морозова. Гречка по-подільськи. Дотримання подільської інтенсивноі технології вирощування гречки дає змогу втричі підвищити врожайність иієєї культурі./ Морозова Л.// The Ukrainian Farmer. - 2014. - травень. - C. 76-77.

5. Надкернична О.В., Халеп Ю.М., Йовенко А.С., Ушакова М.А., Інститут с.г. мікробіології та агропромислового виробництва НААН. Мікробний препарат діазобактерин для передпосівної обробки гречки./ Надкернична О.В., Халеп Ю.М., Йовенко А.С., Ушакова М.А.// ПртнерАгро. - 2016. - №3 (89) - березень. - С. 18.

6. Олександра Гордієнко, ст. наук. співроб. Інститут захисту рослин НААН. Біозахист гречки./ Гордієнко О.// Тһе Ukrainian Farmer. - 2014. - травень. - C. 74-75.

7. Р.Грищенко, канд. с.-г. наук, О.Любич, канд. с.-г. наук, ННЦ «Інститут землеробства НААН». Вирощування гречки в післяукісних посівах./ Р.Грищенко, О.Любич //Пропозищія. - 2016. - № (251) 6/16. - С. 46-48.

8. В.Я. Хомина, д. с/х н., ПДАТУ, В.М. Бурига, к. с/х н., О.Д. Пастух, фермер ПГАТУ. Проверка на совместимость: гречиха и просо./ В.Я. Хомина, В.М. Бурига, О.Д. Пастух //Агробизнес Сегодня. - 2016. - № 21. - С. 46-48.

9. Володимир Іванишин, проф-р, ректор, Руслан Гаврилянчик, к.с/2.н, доцент, перший проректор, Віталій Бурдига, к.с/ح.н., директор НДІКК ім. О. Алексєєвої ПДАТУ Подільскій державний аграрно-технічний університет, Іван Бойко, директор ТзОВ «Жива земля Потутори». Фермерська екогречка/ Іванишин В., Гаврилянчик Р., Бурдига В., Бойко I.// The Ukrainian Farmer. - 2016. - вересень. - C. 74-75.

Надійцла 07.11.2016. До оруку 28.02.2017 Адреса для переписки: вул. Канатна, 112, м. Одеса, 65039 